\title{
RisK Allocation PROVISIONS IN ENERgY INDUSTRY AgreEMENTS: ARE We GetTING IT Right?
}

\author{
NiCK KANGLES, R BEN ROGERS, \\ ZAHRA ALLIDINA, AND CHRIS HARRIS*
}

After reviewing a number of Canadian legal principles relating to indemnities, this article reviews risk allocation provisions used in certain segments of the oil and gas industry in Canada with a view to exploring the rationale behind the use of different risk allocation regimes and combinations thereof, and constraints to the enforceability of such provisions. The authors then discuss select issues that should be taken into account when reviewing, negotiating, and drafting these types of provisions.

\begin{abstract}
Après avoir examiné nombre de principes juridiques canadiens en matière d'indemnités, cet article porte sur les dispositions relatives à la répartition du risque utilisées dans certains segments du secteur pétrolier et gazier du Canada afin d'explorer le raisonnement justifiant le recours à plusieurs régimes de répartition de risque, la combinaison de ces régimes et les limites de la force exécutoire de ces dispositions. Les auteurs discutent ensuite de quelques questions devant entrer en compte au moment d'examiner, de négocier, et de rédiger ces dispositions.
\end{abstract}

\section{TABLE OF CONTENTS}

I. INTRODUCTION . . . . . . . . . . . . . . . . . . . . . . . . . . . . . . . 340

II. CANADIAN INDEMNITY LAW PRINCIPLES AND ISSUES $\ldots \ldots \ldots \ldots \ldots \ldots . \ldots 341$

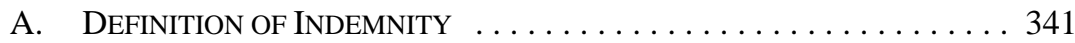

B. StATUtORY LiMitATIONS . . . . . . . . . . . . . . . . . . . 341

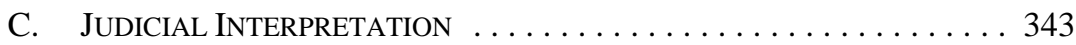

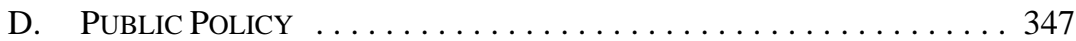

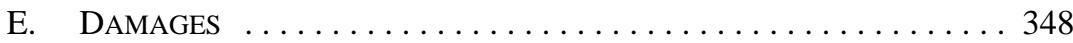

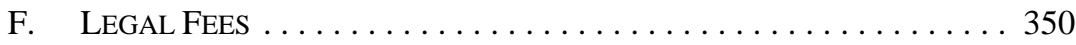

G. GuARANTEE ............................... 350

H. Hold/SAVE HARMLESS . . . . . . . . . . . . . . . . . . . . 351

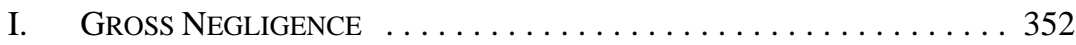

J. THIRD PARTY BENEFICIARIES $\ldots \ldots \ldots \ldots \ldots \ldots \ldots \ldots \ldots$

III. OIL FIELD SERVICE AND DRILLING CONTRACTS -

Is CANADA Out Of STEP With THE Rest Of THE WoRLd? . . . . . . . . . . 355

IV. The Purchase AND SALE AgREEMENT -

Simple TRANSACtion, Complex Asset -

A LiABILITY REgIME FOR All OCCASIONS . . . . . . . . . . . . 358

V. The Joint OPERATing AgreEMENT OR Co-OWNERShip AgreEMENT -

ALLOCATING RISK FOR MUTUAL BENEFIT . . . . . . . . . . . . . . . . . . . 363

VI. DRAFting Suggestions $\ldots \ldots \ldots \ldots \ldots \ldots \ldots \ldots \ldots \ldots \ldots \ldots$

Norton Rose OR LLP, Calgary, Alberta. The authors wish to acknowledge, with gratitude, the assistance provided by Breanne Campbell, Cameron Greaves, Jaclyn Hesje, Kym Hryciw, Sarah Lulman, Anton Tchajkov, and Ilsa Tejada-O’Reilly during the preparation of this article. 


\section{INTRODUCTION}

The liabilities that can arise from transactions, projects, and other industry activities in the oil and gas sector are potentially huge and can raise complicated issues for the parties involved. As a result, it is no surprise that risk allocation provisions can be among the most complex terms of our energy contracts and can consume relatively large amounts of negotiation and drafting time. There is also no doubt that many commercial lawyers make the mistake of treating indemnity and liability provisions as if they are boilerplate. As a result, one commentator has suggested that indemnity provisions tend to be the least successfully negotiated. ${ }^{1}$

Given the comprehensive system of risk allocation provided by our common law system through tort and contract law, together with federal and provincial statutes and local laws, one might question why parties include additional risk allocation provisions in their agreements. The obvious response, which will be examined in more detail in this article, is that they do so in order to provide greater certainty and to order their commercial affairs by allocating risk in a manner different from that which would otherwise be provided by law.

This article is not intended to provide an extensive review of the law in Canada relating to risk allocation or indemnity, nor does it purport to constitute a treatise thereon. ${ }^{2}$ Rather, this article will review the relevant Canadian law and then, against that backdrop of applicable legal principles, review a few selected types of agreements commonly used in the oil and gas industry and provide an analysis of the prevailing methods of risk allocation. Following that analysis, the article will discuss some practical ideas to assist in understanding, using, and drafting these types of provisions.

There are numerous ways in which an indemnity can be used to provide benefits, remedies, relief, or processes that would not otherwise be available, including:

- $\quad$ extending an indemnity to those that are not privy to the agreement;

- $\quad$ broadening or narrowing the scope of the claim that the indemnity captures;

- $\quad$ allocating risk between the parties at the time of contracting;

- $\quad$ reducing potential for litigation and related expenses;

- $\quad$ extending limitation periods;

Genevieve Macattram, "How Can the Indemnity Clause Expand or Limit the Responsibility For Liability of the Parties in International Oil and Gas Contracts?” (2005-2006) 10 Centre for Energy, Petroleum \& Mineral Law \& Policy Annual Review at 2, online: Centre for Energy, Petroleum \& Mineral Law \& Policy <http://www.dundee.ac.uk/cepmlp/car/html/car10_editorial.php>.

2 There is recent literature on this topic from other jurisdictions including the United States and the United Kingdom, but not from Canada. See e.g. ibid; D Hull Youngblood, Peter N Flocos \& Skip Durocher, "Risk Transfer Provisions in Commercial Contracts: Strategies for Negotiating Indemnity, Insurance and Limitation of Liability Clauses” (Teleconference/Webinar, 30 September 2010), online: Strafford $<$ http://www.straffordpub.com>. 
- $\quad$ providing compensation for losses or costs not available under the common law;

- $\quad$ providing for issues related to process, such as the selection of defence counsel to represent the indemnitor and the indemnitee; and

- $\quad$ providing for the adoption of more than one type of risk allocation regime.

The goal of negotiating a risk allocation regime within a contract should not, in most cases, be to beat the other side into submission and extricate one party from all exposure to liability. Rather, the goal is to arrive at a mutually agreed upon risk and liability sharing regime, having regard to the sometimes conflicting notions of fairness (or perceived fairness), industry standards, practicality, availability of insurance or other risk mitigation measures, and business efficacy.

\section{CANAdian INDEMnity LAW PRINCIPLES AND IsSUES}

\section{A. DEFINITION OF INDEMNITY}

There are almost as many definitions of "indemnity” as there are articles and textbooks on the topic. The writers of one article have defined it as "a contract between two parties whereby one agrees to cover any liability, loss or damage sustained by the other from some contemplated act or condition, or damage resulting from a claim or demand of a third person." 3 Another way of defining the term is to characterize it as compensation paid for loss or injury which can include, among other methods of compensation, cash payments, repairs, replacement, and reinstatement. Regardless of the particular definition adopted, it is critical to bear in mind that in order to be responsible for indemnification, it is not necessary for the indemnitor to have caused the loss suffered by the indemnitee.

Further, as indemnities can deviate from the traditional understanding of risk distribution (such as the common law concepts of fault and negligence or breach of contract), contractual indemnities can be interpreted differently depending on the jurisdiction. For example, unlike certain other jurisdictions, Canadian common law does not provide a right to indemnity. Accordingly, the creation of a right to be indemnified may arise by contract or may be created through legislative means. Therefore, a review of the principles of indemnity law in Canada and certain other jurisdictions is appropriate for the purposes of this article.

\section{B. STATUTORY LIMITATIONS}

While there is no legislation in Canada that restricts or prohibits indemnification, several jurisdictions have enacted statutes prohibiting certain types of indemnity provisions. In the United States, these prohibitions affect oil field service contracts in particular. Generally,

Penny L Parker \& John Slavich, “Contractual Efforts to Allocate the Risk of Environmental Liability: Is There a Way to Make Indemnities Worth More Than the Paper They Are Written On?” (1991) 44:4 Southwestern Law Journal 1349 at 1351. 
such statutes prohibit indemnity clauses that indemnify against bodily injury, death, or property damage arising from the indemnitee's own negligence. ${ }^{4}$

As an example, the Texas Oilfield Anti-Indemnity Statute ${ }^{5}$ was enacted to protect against inequities that often arose between small contractors and larger oil companies. Prior to the enactment of the TOAIS, indemnity provisions in oil field service agreements unfairly shifted risk to contractors, as a result of their weaker bargaining positions, by requiring them to indemnify their oil company counterparties against that counterparty's own negligence. Subject to certain exceptions, the TOAIS applies to void and render unenforceable agreements that purport to indemnify a party against loss or liability for damage that is caused by the party's own or concurrent negligence and which arise from personal injury or death, property damage, or any other loss that arises from personal injury, death, or property damage. ${ }^{6}$ The TOAIS facilitates a more equitable risk allocation amongst the parties than might otherwise result, and provides protection against agreements that attempt to indemnify a negligent indemnitee.

Excluded from the operation of the TOAIS are certain forms of industry agreements. For example, indemnities in joint operating agreements (JOAs) were not included in the provisions of the TOAIS since JOAs: (1) provide for the sharing of costs or losses arising from joint operations; (2) are commonly understood and desired by parties; (3) encourage mineral development; (4) do not offend public policy; and (5) are enforceable so long as the sharing of costs or losses are not expressly excluded. ${ }^{7}$ Further, an indemnity provision is permitted under the TOAIS so long as the parties agree that "the indemnity obligation will be supported by liability insurance coverage," 8 and in the case of a mutual indemnity provision, so long as such "indemnity obligation is limited to the extent of the coverage and dollar limits of insurance or qualified self insurance each party as indemnitor has agreed to obtain." 9

Similar to the TOAIS, the Louisiana Oilfield Anti-Indemnity Act ${ }^{10}$ prohibits an indemnity provision that indemnifies the indemnitee against losses resulting from the indemnitee's own negligence. Additionally, if any such agreement requires "any other form of insurance protection which would frustrate or circumvent the prohibitions" of the LOAIA, such agreement is void. ${ }^{11}$ If the indemnified party pays for its own liability insurance, such indemnity agreements are permitted under the LOAIA as such an arrangement does not result in a transfer of risk from the indemnitee to the indemnitor. ${ }^{12}$

Owen L Anderson, “The Anatomy of an Oil and Gas Drilling Contract” (1990) 25:3 Tulsa LJ 359 at 422. Tex Civ Prac \& Rem Code Ann tit 6, §§ 127.001 - 127.007 (LEXIS through 2011 First Called Sess) [TOAIS].

Ibid at $\S 127.003$.

Ibid at $\S 127.002(\mathrm{c})$.

Ibid at $\S 127.005(\mathrm{a})$.

Ibid at $\S 127.005(\mathrm{~b})$.

La Rev Stat Ann § 9:2780 (LEXIS through 2011 Sess) [LOAIA].

Ibid at $\S 2780(\mathrm{G})$.

Marcel v Placid Oil Co, 11 F (3d) 563 at 569 (5th Cir 1994); Patterson v Conoco, Inc, 670 F Supp 182 at 184 (WD La 1987). 
It is unlikely that similar legislation will be enacted in Canada; however, it is instructive to understand that this type of legislation exists and can affect the enforceability of indemnity provisions in certain jurisdictions. ${ }^{13}$

\section{JUDICIAL INTERPRETATION}

Divergent rules of interpretation can make interpreting indemnities challenging. As a general rule, Canadian courts will seek the true construction of an agreement to determine the parties' intentions, ${ }^{14}$ and conceivably the parties' reasonable expectations. The doctrine of contra proferentem ${ }^{15}$ can be used by courts as a rule where the language is unclear.

One of the main lines of judicial thought on the doctrine of contra proferentem comes from Mobil Oil Canada Ltd v Beta Well Service Ltd. ${ }^{16}$ A portion of that decision was quoted with approval by the Court in Sinclaire v South Trail Shell (1987), and the Court held: "indemnity clauses should be read in the overall context of the agreement and also should be read, where the total [is] unclear, in light of the principle of contra [proferentem]." ${ }^{17}$

In contrast, the Court in Travellers Indemnity Co of Canada $v$ Werner was faced with "arguably the worst piece of draftsmanship that [the judge had] seen." ${ }^{18}$ Nevertheless, the Court struck out the meaningless language and gave the remaining words their reasonable meaning rather than relying on the doctrine of contra proferentem.

A further retreat from the doctrine of contra proferentem was exhibited by the Court in Herron $v$ Hunting Chase Inc, which provided that rather than relying on the doctrine of contra proferentem, "the plain and ordinary meaning of each contract must be assessed in its own context with a focus on the intention of the parties."19

While it is arguable that the "reasonable interpretation" rule of contractual interpretation is the better statement of the law given the more recent decision in Herron, drafting parties should always be aware of the application of the doctrine of contra proferentem, which could lead to unforeseen and unintended consequences.

A separate line of cases has arisen for circumstances where an indemnitee is seeking indemnification from damages that arose from its own negligence. The leading case is the Privy Council decision in Canada Steamship Lines, Ltd v Regem, which applied a three-part test (the Canada Steamship Test) for interpreting an indemnity provision under which the Crown made a claim of indemnity for losses arising from the negligence of its own servants: See also Alaska Stat § 45.45.900 (LEXIS through 2010 Sess); Kan Stat Ann § 16-121 (LEXIS through 2010 Supp ); Utah Code Ann § 13-8-1 (LEXIS through 2011 2nd Special Sess); N Mex Stat Ann § 56-72 (LEXIS through 2011 First Sess); Wyo Stat Ann § 30-1-131 (LEXIS through 2011 Sess). 2 SCR 718. construed against the party that drafted it. (1974) 2 AR 186 at para 16 (Alta SC (AD)) [Mobil Oil]. 2002 ABQB 378, [2002] 6 WWR 106 at para 43 [Sinclaire]. (1985), 37 Alta LR (2d) 93 at 95 (CA) [Travellers Indemnity]. 2003 ABCA 219, 330 AR 53 at para 34 [Herron] [footnotes omitted]. 
i) If the clause contains language which expressly exempts the person in whose favour it is made (hereafter called "the proferens") from the consequence of the negligence of his own servants, effect must be given to that provision. Any doubts which existed as to whether this was in the law in the Province of Quebec were removed by the decision of the Supreme Court of Canada in Glengoil S.S. Co. v. Pilkington. ii) If there is no express reference to negligence, the court must consider whether the words used are wide enough, in their ordinary meaning, to cover negligence on the part of the servants of the proferens. If a doubt arises at this point, it must be resolved against the proferens in accordance with art. 1019 of the Civil Code of Lower Canada: "In cases of doubt, the contract is interpreted against him who has stipulated and in favour of him who has contracted the obligation.” iii) If the words used are wide enough for the above purpose, the court must then consider whether "the head of damage may be based on some ground other than that of negligence” to quote again Lord Greene, M.R., in the Alderslade case. The "other ground” must not be so fanciful or remote that the proferens cannot be supposed to have desired protection against it, but, subject to this qualification, which is, no doubt, to be implied from Lord Greene's words, the existence of a possible head of damage other than that of negligence is fatal to the proferens even if the words used are, prima facie, wide enough to cover negligence on the part of his servants. ${ }^{20}$

Thus, the third part of the Canada Steamship Test still requires a review of the intention of the parties, and the approach at this point is to ask whether the alternative head of damage was one within the contemplation of the parties. ${ }^{21}$

As seen in Canada Steamship, the courts are likely to apply the doctrine of contra proferentem for a claimant seeking indemnification for its own negligence. The basis for the application of the doctrine of contra proferentem in these circumstances is found in Alderslade $v$ Hendon Laundry, $L t d,{ }^{22}$ a decision considered by the Privy Council in Canada Steamship. In that case, Lord Greene, MR stated that

if a contracting party wishes ... to limit his liability in respect of negligence, he must do so in clear terms, and in the absence of such clear terms the clause is to be construed as relating to a different kind of liability and not to liability based on negligence. ${ }^{23}$

The Privy Council in Canada Steamship noted that "liability for the negligence of others must surely be imposed by very clear words, if it is to be imposed at all,"24 thereby recognizing that taking on liability for the negligence of another is "a very remarkable and burdensome obligation.",25

The Canada Steamship Test was applied in Kocherkewych $v$ Greyhound Canada Transportation Corp ${ }^{26}$ in which the plaintiff tripped over a suitcase while waiting at a bus depot and claimed that the bus driver, an employee of Greyhound Canada Transportation Corp (Greyhound), was negligent in placing the suitcase behind her. The bus depot was owned by Northland Properties Ltd and operated by R\&Z Warman Enterprises Ltd (R\&Z), as agent of Greyhound. The underlying question was whether the terms of the agency

[1952] 1 All ER 305 at 310 (PC) [Canada Steamship] [footnotes omitted].

Ibid at 310-11.

[1945] 1 All ER 244 (CA).

Ibid at 245.

Canada Steamship, supra note 20 at 312.

Ibid at 311.

2006 BCSC 534, 53 BCLR (4th) 360 at paras 40-62 [Kocherkewych]. 
agreement between R\&Z and Greyhound protected Greyhound against the negligence of its employees. After a thorough review of the Canada Steamship Test, the Court noted that

the language used in the Agreement, in its ordinary meaning, is not wide enough to protect Greyhound against the negligence of its own employees. If that had been the intention of the parties, it would have been a very simple matter to say so clearly. ${ }^{27}$

While the Canada Steamship case has been acknowledged as the leading authority in interpreting contractual indemnity purporting to absolve parties for their own negligence, the three-step test has not always been systematically applied. For instance, in Consumers' Gas Co v Peterborough (City of), the Supreme Court of Canada referred to the Canada Steamship Test as being applicable, but then turned to an examination of the subject indemnity provision to determine whether it was sufficiently clear to include negligence. ${ }^{28}$ In reaching its decision, the Court quoted the Ontario Court of Appeal: "If one is to be protected against and indemnified for one's own negligence there would have to be an indemnity clause spelling out this obligation on the other party in the clearest terms."29

In Travellers Indemnity, the Court held that an indemnity requires clear and strong language if an indemnity is to extend to a loss caused by the party's own negligence. Similarly, several American jurisdictions also require express language in order for a party to be indemnified against its own negligence, further emphasizing the point that protection against a party's own negligence is not implied in an indemnity clause. ${ }^{30}$ Instead, where protection for negligence is sought, American courts have required that express wording such as "including such party's negligence” must be included in the indemnity clause in order for such protection to be afforded to the indemnitee. ${ }^{31}$

A further interpretive issue that has been addressed by Canadian courts is whether an indemnity provides indemnification to the indemnitee for losses suffered directly by the indemnitee or only losses suffered by third parties who then seek compensation from the indemnitee. This issue was dealt with in Mobil Oil, in which the Court, choosing to rely on a restrictive interpretation of the subject indemnity provisions, held that an indemnity must clearly state that indemnification will be given to the indemnitee for its own direct losses before such effect will be given by the Court. ${ }^{32}$ In a subsequent case, the Court in Herron stated that "[r]ather than relying on Mobil Oil, the plain and ordinary meaning of each contract must be assessed in its own context with a focus on the intention of the parties."33 The Court found that the indemnity provision included coverage for third party losses, but did not limit protection only to such third parties and was sufficiently broad to cover first party losses (those suffered by the indemnitee). ${ }^{34}$

Ibid at para 47.

[1981] 2 SCR 613 at 616 [Consumers' Gas].

Ibid. Similarly, in Blackwater v Plint, 2001 BCSC 997, 93 BCLR (3d) 228 at para 315, aff'd 2005 SCC 58, [2005] 3 SCR 3, the applicability of the Canada Steamship Test was acknowledged.

See e.g. Ethyl Corp v Daniel Construction Co, 725 SW (2d) 705 at 708 (Tex Sup Ct 1987).

B-F-W Construction Co, Inc v Garza, 748 SW (2d) 611 at 613 (Tex Ct App 1988).

Supra note 16 at para 16 .

Supra note 19 at para 34.

Ibid at para 35 . 
It is now advisable for indemnities to be drafted in a manner that expressly cover an indemnitee for its own direct losses. ${ }^{35}$ In TransCanada Pipelines Ltd v Potter Station Power Ltd Partnership, the defendant had provided the plaintiff with an indemnity in a contract allowing for the use of waste heat derived from the plaintiff's gas compressor. ${ }^{36}$ The indemnity provided that the defendant would:

[I]ndemnify and save harmless TransCanada from and against all liability, actions, claims, losses, costs and damages which might be brought against or suffered by TransCanada and which TransCanada may incur, sustain or pay arising out of or in connection with

(a) construction, operation and maintenance of the [Potter] Facility (including the Duct System);

(b) the negligence or willful misconduct of Potter Power, its directors [etc.] arising out of or incidental to this Agreement; or

(c) a breach by Potter Power of any of the terms and conditions set forth in this Agreement,

except to the extent that such losses or damages result from the negligence or willful misconduct of TransCanada. ${ }^{37}$

When the gas compressor was damaged by the operations of the defendant, it was argued that the indemnity provided for in the agreement only required the defendant to indemnify the plaintiff against damages incurred by third parties. ${ }^{38}$ The Court first noted that "the case law does not establish a general principle that wherever words of indemnity are found, the obligation created is confined to responding to claims made against the indemnitee by third parties." 39 The Court continued: "The principle exemplified by every case cited is that the obligation is governed by the words chosen, when placed and read in their context. Context consists of two elements: the background, business purpose analysis; and the context of words within which the difficult passage is found."

The Court admitted evidence that the plaintiff was of the view that it would only permit the construction and operation by the defendant of the waste heat facility if it did not interfere with the operation of the plaintiff's facility, and that this was the business purpose for the indemnity. ${ }^{41}$ The Court then focused on the words "suffered by TransCanada" to conclude that the indemnity was not only limited to damage suffered by third parties, but extended to damages suffered by the plaintiff directly. ${ }^{42}$ On this basis, the defendant's motion for summary judgment was dismissed. If the indemnity in question had been drafted in a manner that expressly covered direct losses, the parties could possibly have avoided litigation and the external and internal costs associated therewith.

Don Greenfield \& Jay Todesco, “Fundamental Aspects of Oil and Gas Law Revisited” (2004) 42:1 Alta L Rev 75 at 95.

(2002), 22 BLR (3d) 210 at para 1 (Ont Sup Ct) [TransCanada].

Ibid at para 5.

Ibid at para 6 .

Ibid at para 35.

Ibid.

Ibid at paras 8-13, 39.

Ibid at para 36. 
A further issue is the uncertainty surrounding whether a party should be indemnified for losses arising from its own breach of contract. Although there is a lack of Canadian authority in determining this issue, the English courts have provided different responses depending on the wording of the indemnity provision considered. One example is Deepak Fertilisers \& Petrochemicals Corp v ICI Chemicals \& Polymers Ltd, where the Court reviewed the trial judge's conclusion on this point, specifically noting that “[d]espite the wide wording 'against any and all liabilities' the language is not in our judgment appropriate to provide an indemnity against the consequences of ... breach of express contractual obligations."43

\section{Public Policy}

The widespread use of contractual indemnity provisions to allocate risk has the potential to raise public policy concerns. If liability is allocated to a party incapable of sufficiently compensating contemplated losses, or where the allocation of risk is the unconscionable result of asymmetrical negotiating power, the result may pose a risk to the public. In the context of commercial agreements, it can generally be assumed that the parties, while not necessarily having equal capabilities, are sophisticated commercial organizations. In this case, the public policy concern regarding relative bargaining power is less persuasive given the propensity of Canadian courts to allow such parties to contract freely. However, the potential for indemnities to provide an incentive for parties to act in a careless or dangerous manner, or alternatively, to negate the incentive to take reasonable steps to mitigate potential damage to person or property are both, rightly or wrongly, argued as public policy reasons in favour of limiting the extent of contractual indemnities.

Indemnity provisions protecting a party against its own gross negligence or wilful misconduct may clearly express the intention of the parties to protect against such behaviour, but such provisions may nevertheless offend public policy. Generally, in Canada and the US, case law with respect to the enforceability of indemnity provisions that protect a party against its own gross negligence or wilful misconduct is not very well developed. ${ }^{44}$ In Smith v Golden Triangle Raceway, a spectator was injured while standing in the pit area of a raceway and had signed a document that was intended to release the defendant and others from liability from their own gross negligence. ${ }^{45}$ The Court held that "a term in a release attempting to exempt one from liability or damages occasioned by gross negligence is against public policy."46

Public policy concerns are, more often than not, outweighed by the benefits to the parties that arise from the inclusion of a contractual indemnity. The elimination of redundant insurance coverage and a reduction in unnecessary litigation and associated expense are commonly cited as reasons for using a contractual indemnity provision. ${ }^{47}$ The ability of parties to more clearly understand their respective risk exposure, and to take steps to reduce such exposure, is another key benefit of indemnity provisions. While reducing costs for both

43 [1999] 1 Lloyd's LR 387 at para 45 (Court of Appeal, Civil Division) [Deepak].

$44 \quad$ See e.g. National Railroad Passenger Corp v Consolidated Rail Corp, 698 F Supp 951 (DDC 1988) which only contains strong obiter dicta suggesting that indemnification for gross negligence would be contrary to public policy in the US.

708 SW (2d) at 574-75 (Tex Ct 1986) [Smith].

Ibid at 576 .

See e.g. Darty v Transocean Offshore USA, Inc, 875 So (2d) 106 (La 4th Cir App Ct 2004) [Darty]. 
parties, potential liability is also established at the outset of the contract and reduces the potential for adversarial relations during the term of the agreement. While a contractual indemnity provision does not assure the parties of a swift resolution to potential disputes, it does provide the parties with a level of certainty at the time of contracting and throughout the duration of the contract.

\section{E. DAMAgES}

Determining liability and awarding damages to injured parties through litigation is a costly burden most contracting parties wish to avoid. The use of a contractual indemnity provides a means of amending the applicability of the common law to the agreement and allocating risk in the manner most preferable to the parties.

In the absence of a specific agreement, the common law allocates liability on the basis of a breach of a duty or fault, with consideration of negligence and breach of contract at the forefront. Subject to the doctrines of remoteness of damages and frustration of contract, the party in breach must compensate the injured party.

By modifying the common law rights and obligations of the parties, contractual indemnity provisions permit the indemnitee to recover damages in circumstances where such indemnification would not be possible under the common law, such as where there has been contributory negligence. A contractual indemnity provides certainty at the time of contracting, as each party knows what it is to indemnify for and what it will be indemnified for (the group of beneficiaries is also established) and, often, the approximate cost or amount in damages is known at the time of contracting.

When negotiating an indemnity, of utmost importance to the contracting parties are the differences between the remedies they receive under the indemnity clause as opposed to those remedies they would receive under the common law.

The common law places limits on the extent of damages that may be recovered by a plaintiff. For instance, in the case of a plaintiff seeking damages for breach of contract, the fault of the defendant must first be determined using common law principles. Subsequently, damages must be proven by the plaintiff. The seminal case in this regard is Hadley $v$ Baxendale. ${ }^{48}$ In Fidler v Sun Life Assurance Co of Canada, the Supreme Court of Canada described the two-part test as enunciated in Hadley:

Where two parties have made a contract which one of them has [broken,] the damages which the other party ought to receive in respect of such breach of contract should be such as may fairly and reasonably be considered either arising naturally, [i.e.], according to the usual course of things, from such breach of contract itself, or such as may reasonably be supposed to have been in the contemplation of both [parties] at the time they made the contract, as the probable result of the breach of it. ${ }^{49}$ 
Under the common law, a plaintiff can only obtain compensation pursuant to breach of contract for those damages that are: (1) reasonably foreseeable; or (2) foreseeable in the reasonable contemplation of the parties at the time of negotiation.

Alternatively, the trigger for indemnity can be determined by the parties as specified in their contractual indemnity, as opposed to relying on the strict fault-based requirement of the common law. ${ }^{50}$ For instance, an indemnity clause can compensate for losses that may not be recognized at common law, such as losses caused by a party's own negligence, so long as the indemnity is properly drafted to indemnify for such losses. Indemnity provisions may also narrow the scope of liability. For instance, a trigger for indemnity could be limited to a breach of representations, warranties, and covenants contained in the agreement. In addition, contractual indemnities provide the parties with an opportunity to define the possible remedies. Contracting parties may even wish to completely contract out of the common law remedies and rely solely on the remedies provided for in the indemnity.

Using a contractual indemnity also provides one with the opportunity to address certain types of damages which one wishes to contract out of. For instance, indemnity provisions often include language that excludes “indirect” or “consequential” damages (and often times both) from the potential liability of the indemnitor. There are several examples of the Supreme Court of Canada awarding damages that were not the direct, physical result of a defendant's actions. ${ }^{51}$ However, in terms of determining exactly what types of damages are excluded using the terms "indirect" or "consequential," there is very little case law that assists us.

In one of the clearest considerations of the meaning of indirect damages by a Canadian court, the British Columbia Supreme Court considered a limitation of liability clause that excluded "loss of profit, indirect, special, punitive or consequential damages." ${ }^{2}$ It should be noted that the Court in this case did not appear to distinguish between the various types of damages specified in the exclusion clause, but instead chose to conduct an analysis of "indirect and consequential damages," sometimes using the terms interchangeably. The Court quoted John Swan as authority for the distinction between direct and indirect damages:

One is likely to encounter in many kinds of agreements a distinction between "direct" and "indirect" damages, and descriptions of the latter as "consequential” or "incidental”. In a contract of sale, the seller may agree to be liable for "direct" damages but not for "indirect" or "consequential” damages. It is convenient to adopt a usage that corresponds to that frequently used by solicitors and by the courts.... The terms "consequential”, "incidental” and "indirect” damages refer to damages that are in addition to or that arise as a consequence of the direct damages of the promisor's breach. ${ }^{53}$

$50 \quad$ See e.g. Macattram, supra note 1 at 18.

$51 \quad$ See Rivtow Marine Ltd v Washington Iron Works (1973), [1974] SCR 1189; Winnipeg Condominium Corp No 36 v Bird Construction Co Ltd, [1995] 1 SCR 85; Bow Valley Husky (Bermuda) Ltd v Saint John Shipbuilding Ltd, [1997] 3 SCR 1210; Design Services Ltd v Canada, 2008 SCC 22, [2008] 1 SCR 737.

52 Agfaphoto Canada Inc v Overwaitea Food Group Ltd, 2008 BCSC 1287, 171 ACWS (3d) 841 at para 21 [Agfaphoto].

53 John Swan, Canadian Contract Law, 1st ed (Markham, ON: LexisNexis Butterworths, 2006) at 296-97 [footnote omitted], as cited in Agfaphoto, ibid at para 25. 
This description of the difference between direct and indirect damages is in line with the general understanding of the distinction in case law and other sources: that direct damages flow directly from the act giving rise to the cause of action, whereas indirect damages flow from, but are not directly caused by, that act. It is also worthwhile to note that the Court's treatment of the exclusion clause in Agfaphoto, as well as Swan's discussion, raise the point that there does not appear to be a clear distinction, whether judicially or by legal scholars, between "indirect” and “consequential” damages.

\section{F. LEGAL FEES}

When drafting an indemnity clause in order to provide for indemnification of legal costs, it is essential to understand how various wordings of such a clause will be interpreted. One of the most common forms of such an indemnity is for costs "on a solicitor-client basis." A subsequent variation of this provision has provided for costs "on a solicitor and his own client basis.” In more recently drafted agreements, "legal costs on a full indemnity basis” has been utilized.

One of the most definitive interpretations of the terms "solicitor-client" and "solicitor-andown-client" is found in Colborne Capital Corp v 542775 Alberta Ltd. ${ }^{54}$ In this case, the Court distinguished the two terms, holding that "solicitor-client" costs are not recoverable on a full indemnity basis, whereas "solicitor-and-own-client costs" are. ${ }^{55}$ Perhaps more instructive to the drafter of a contractual indemnity, the Court stated: "Even though we referred to 'solicitor-client' costs in the Reasons for Judgment, we expressly stated our intention that the cost award was to be a full indemnity."56

\section{G. GUARANTEE}

The differences between a contract for indemnity and a contract for guarantee can cause confusion and often leads to litigation in order to resolve the issue of liability as between the parties involved. In Anson's Law of Contract,

a contract of indemnity ... [is] a promise to save another harmless from the result of a transaction ... [entered into] at the instance of the promisor ... [where] the promisor makes himself primarily liable and undertakes to discharge the liability in any event. ${ }^{57}$

In a contract of guarantee on the other hand, the guarantor "promises to discharge the debtor's liability if the debtor should fail to do so." ${ }^{\text {" }}$ A guarantee is a secondary obligation that is based upon a contract between a debtor and creditor whereby the guarantor promises to compensate the creditor in case of a default by the debtor. An indemnity, on the other hand, is a "primary obligation" for the indemnitor to compensate the indemnitee if the indemnitee "suffers a loss covered by the terms of the indemnity" contract. ${ }^{59}$

1999 ABCA 361, 250 AR 79.

Ibid at para 25.

Ibid.

AG Guest, Anson's Law of Contract, 24th ed (London: Oxford University Press, 1975) at 76 [emphasis omitted].

Ibid [emphasis omitted].

Greenfield \& Todesco, supra note 35 at 94-95. 
This distinction came to light in Zurich Insurance Co v Modern Marine Industries Ltd. ${ }^{60}$ In this case, the surety guaranteed prospective ship owners, by way of a performance bond, that certain shipbuilders would deliver the ships. The shipbuilders defaulted on their contractual obligations owed to the ship owners who then collected on the performance bond against the surety. The surety then sought indemnity from the shipbuilders, who in turn, claimed that the surety had provided them a guarantee that obligated the surety to discharge the shipbuilder's liability in the event of their default under the shipbuilding contract, with no subsequent liability to the shipbuilders. The Court ruled against the defendant shipbuilders, holding that the indemnity agreement "is not a contract of guarantee under which the [defendants] agreed with [the plaintiff] to answer for the debt to [the plaintiff] of the third party [the ship building company]." ${ }^{, 1}$ Rather, according to the Court, "it is an independent agreement whereby the [defendants] agreed directly with [the plaintiff] to reimburse [the plaintiff] for any payments it was called upon to make under the bonds." 62 Here, the plaintiff insurance company had a contract for guarantee with the ship owners and a contract for indemnity with the shipbuilders.

\section{H. Hold/SAVE HARMLESS}

While the concepts of "indemnity" and "hold harmless" or "save harmless" are often paired together in a contractual indemnity, it is important to understand the distinction. One initial issue of note is the use of "hold harmless" as compared to "save harmless." A review of the term "save harmless" in Black's Law Dictionary refers the reader to the definition of "hold harmless," which in turn refers the reader to the definition of "indemnity." "63 There is also no apparent distinction between "hold harmless" and "save harmless" in Canadian case law. In fact, multiple cases have used the terms interchangeably when considering the effect of the clause. ${ }^{64}$

A more pertinent issue to the drafter of a contractual indemnity is the difference between the obligation to indemnify and the obligation to hold or save harmless. A leading case on the difference between the two obligations is Stewart Title Guarantee Company v Zeppieri. ${ }^{65}$ The Ontario Superior Court of Justice held that

\footnotetext{
"save harmless" imposes an additional obligation that goes beyond the obligation to "indemnify". To make a person whole after the fact may satisfy an obligation to indemnify in the proper case. But, to require a person protected by a promise to save him harmless first to pay out moneys in respect of a claim, before he can call on his counter-party to honour his promise, hardly saves him harmless.... In my view, [a requirement to hold harmless] would include not only paying any damages for which a member might become liable, but also covering the ongoing costs incurred in defending such claims. ${ }^{66}$
}

(1996), 146 Nfld \& PEIR 91 (Nfld CA) [Zurich].

Ibid at para 38 .

Ibid.

Black's Law Dictionary, 8th ed, sub verbo "indemnity" and "hold harmless."

See e.g. Excelsior Life Insurance Co v Saskatchewan (1987), 63 Sask R 35 at paras 4, 6 (QB); Williamson $v$ Guitard (1993), 134 NBR (2d) 305 at para 7 (QB). (2009), 94 OR (3d) 196 (Sup Ct) [Stewart Title]. Ibid at para 20. 
The Court in Stewart Title found additional case law supporting this interpretation of "save harmless." ${ }^{\prime 7}$ The limited case law related to this language suggests that "hold harmless" imposes a greater obligation than indemnification language. However, it is unclear what exactly this additional obligation includes. From the case law it appears that the primary obligation is to defend an indemnitee from the costs of defending an action for the very thing in which the indemnity is meant to provide protection from. Therefore, the obligation to hold harmless appears to arise prior to the duty to indemnify. However, whether "hold harmless" provisions are limited to protection from the costs of defending an action is not clear from the authorities.

\section{Gross NEGLIGENCE}

Despite the lack of clarity in Canadian case law considering an action for indemnification arising out of gross negligence, a review of the concept of gross negligence is worthwhile given the prevalence of gross negligence being excepted out of contractual obligations to indemnify.

In Kingston (City of) $v$ Drennan, ${ }^{68}$ the plaintiff fell on snow on a crossing just before it joined the sidewalk. According to the The Consolidated Municipal Act, 1892, municipal corporations are held liable for accidents that arise as a result of snow and ice on sidewalks if the corporation was grossly negligent. ${ }^{69}$ Refusing to embark on a detailed investigation of the difference between gross negligence and ordinary negligence, the Supreme Court of Canada noted that the meaning of gross negligence, in its view, was "very great negligence."70 The Court found that the defendant corporation was grossly negligent in not fulfilling its statutory duty to keep the streets and sidewalks in repair. ${ }^{71}$

In McCulloch $v$ Murray, ${ }^{72}$ the driver of a motor vehicle was in an accident that caused injury to a gratuitous passenger. The Motor Vehicle Act of Nova Scotia, as it then was, provided the gratuitous passenger (a passenger who does not pay a fare) with a cause of action if the accident was caused by the "gross negligence or wilful and wanton misconduct" of the driver who contributed to the injury. ${ }^{73}$ The Supreme Court of Canada defined gross negligence as "a very marked departure from the standards by which responsible and competent people in charge of motor cars habitually govern themselves." ${ }^{\text {"74 }}$ While this case related to motor vehicle accidents, the judge noted that it was "entirely a question of fact for the jury whether the conduct" of the driver fell into the category of gross negligence. ${ }^{75}$

Similarly, United Canso Oil $v$ Washoe Northern Inc $^{76}$ was an action alleging that an accounting affecting several joint ventures and established to develop a natural gas field in

Ibid at paras 19-22. See Mewburn v Mackelcan (1892), 19 OAR 729 at 738; Kelly v Eldridge, 2006 NBQB 426, 315 NBR (2d) 32 at paras 10-11.

(1897), 27 SCR 46 [Kingston].

SO 1892, c 42, s 531, as amended by SO 1894, c 50, s 13 as amended by 1894, 57 Vict, c 50, s 13.

Supra note 68 at 60 .

Ibid.

[1942] SCR 141 [McCulloch].

SNS 1932, c 6, s 183.

Supra note 72 at 145 .

Ibid.

(1991), 121 AR 1 (QB) [United Canso]. 
Alberta and market the natural gas produced therefrom, was improperly carried out. One responsibility of the managing operators was accounting with respect to the joint operating agreement. The Court found that the outstanding accounting issues were either ignored or a calculated risk was taken that the accounting was correct, or alternatively, that the plaintiff would not pursue these issues and that this amounted to gross negligence which the Court defined as

a very marked departure from the standards by which reasonable and competent companies in a like position

... in charge of joint ventures or accounting should habitually govern themselves. This was a conscious indifference to the rights or welfare of [the affected parties]. ${ }^{77}$

This case also “illustrates the principle that the Operator's liability depends upon the language of the governing operating agreement." ${ }^{, 78} \mathrm{~A}$ "form of joint operating agreement was incorporated which [utilized] a gross negligence standard of care."79

More recently, in Adeco Exploration Co v Hunt Oil Co of Canada Inc, the Court considered whether Hunt Oil Co of Canada Inc (Hunt Oil) was grossly negligent when it failed to properly renew an oil and gas lease. ${ }^{80}$ The parties had entered into a joint operating agreement, with Hunt Oil as operator. ${ }^{81}$ The plaintiffs alleged that Hunt Oil had "breached its contractual duty to keep the leases in good standing; ... was negligent in its renewal process; and that Hunt Oil owed them a fiduciary duty to maintain the leases in good standing." ${ }^{22}$ Prior definitions of gross negligence noted by the Court included "very great negligence" 83 and "conscionable wrongdoing or a very marked departure from the standard of care required." ${ }^{84}$ The Court also noted that a "[c]avalier attitude is a factor in reaching a conclusion of either negligence or gross negligence." ${ }^{85}$ The existence of effective systems to deal with contingencies, or lack thereof, is also a factor to consider, and the Court found that Hunt Oil's system of renewing leases was carried out on an ad hoc basis without proper controls. ${ }^{86}$ In finding Hunt Oil to be grossly negligent, the Court compared Hunt Oil's actions to a system in a law office where "an untrained, unknowing person” was "tasked with ensuring claims are filed in time to meet limitations.",87

\section{J. THIRD PARTY BENEFICIARIES}

A general principle of Canadian contract law is that non-parties to a contract cannot enforce a contract or otherwise make claims under it. Unlike Canadian contract law, many other jurisdictions have allowed third parties to enforce rights under an agreement to which they do not enjoy privity of contract. One example is in the UK, which enacted the Contracts

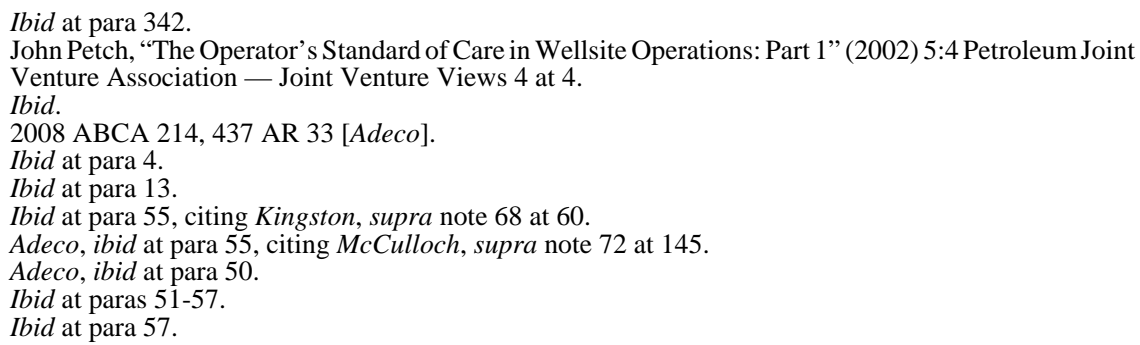


(Rights of Third Parties) Act 1999. ${ }^{88}$ This legislation overrides the doctrine of privity and allows a third party to enforce rights under a contract to which it is not a party. In the US, third party beneficiaries have been recognized by common law since the decision of Lawrence $v$ Fox in $1859 .{ }^{89}$ It is important to understand this issue as most indemnity provisions attempt to extend their benefits to third parties.

In Canada, there are examples of statutory exceptions to the doctrine of privity. For example, section 579 of the Insurance Act of Alberta allows a beneficiary under a life insurance policy to enforce a right of payment to that beneficiary in accordance with the insurance policy (or a collateral declaration made for their benefit) without being a party to the policy itself..$^{90}$ However, unlike jurisdictions such as the UK and the US, there is no overarching statutory or common law exception to the doctrine of privity of contract in Canada. Of note, however, is what has become known as the "principled exception" to the doctrine of privity of contract; a line of cases that began with the Supreme Court of Canada's decision in London Drugs Ltd v Kuehne \& Nagel International Ltd..${ }^{91}$ In this case, which took place in the context of an employer-employee relationship, the Court provided an exception to the doctrine of privity of contract in order to allow negligent employees to enjoy the benefit of a limitation of liability clause between their employer and the harmed customer. ${ }^{92}$ In Fraser River Pile \& Dredge Ltd v Can-Dive Services Ltd, the Court stated that the principled exception was not confined only to situations arising in the employment context, but could apply to other circumstances..$^{93}$ The test for the application of the principled exception as derived from London Drugs and Fraser River is as follows: (1) was it the intention of the parties to the contract that the third party has enforceable rights under the contract? and (2) was the third party performing the very act that the parties to the contract contemplated the third party performing? ${ }^{94}$ In circumstances where both of these questions can be answered in the affirmative, Canadian courts have been willing to find an exception to the doctrine of privity.

What is less clear is to what extent the principled exception rule allows third parties to seek a right of indemnity from an indemnitor under a contract. In other words, does the principled exception as enunciated in London Drugs and Fraser River allow a party to make a claim of indemnity under a contract to which they are not privy? There have been scattered lower court decisions allowing a third party to bring a cause of action in contract, but no upper court has yet to definitively rule on this issue. ${ }^{95}$

The only Canadian common law jurisdiction to address this issue is New Brunswick. Sections 4(1) and 4(3) of New Brunswick's Law Reform Act state:

(UK), 1999, с 31.

20 NY 268 (Ct App 1859); see also Anthony Jon Waters, "The Property in the Promise: A Study of the Third Party Beneficiary Rule” (1985) 98:6 Harv L Rev 1109 at 1111-12.

RSA 2000, c I-3, s 579.

[1992] 3 SCR 299 [London Drugs].

Ibid at 301.

[1999] 3 SCR 108 at paras 31-32 [Fraser River].

Ibid at para 32.

See Michael E Mestinsek \& Matthew OJ Synnott, “It’s Our Party and You're Not Invited: Third Party Beneficiaries in Contract Law"(Paper delivered at the CBA Corporate Counsel Section South, 15 December 2010) at 11, online: Stikeman Elliott LLP <http://www.stikeman.com/cps/rde/xchg/se-en/ hs.xsl/14793.htm>. 
4(1) A person who is not a party to a contract but who is identified by or under the contract as being intended to receive some performance or forbearance under it may, unless the contract provides otherwise, enforce that performance or forbearance by a claim for damages or otherwise.

4(3) The parties to a contract to which subsection (1) applies may amend or terminate the contract at any time, but where, by doing so, they cause loss to a person described in subsection (1) who has incurred expense or undertaken an obligation in the expectation that the contract would be performed, that person may recover the loss from any party to the contract who knew or ought to have known that the expenses would be or had been incurred or that the obligation would be or had been undertaken. ${ }^{96}$

Section 4(3) of the Law Reform Act addresses one of the main policy concerns regarding the recognition of third party rights under contract, specifically, the ability of the parties to a contract to amend the terms of their agreement as they see fit (that is, without the agreement of the third parties). Recognition of third party beneficiaries under an agreement may frustrate the ability of parties to an agreement to freely renegotiate terms. This is a potentially troubling aspect of recognizing third party beneficiaries given that the parties to an agreement that recognizes third party rights will often not have intended to limit their ability to renegotiate terms.

With the exception of New Brunswick, whether a third party may enforce a right of indemnity under Canadian common law is less than certain. ${ }^{97}$ Given the propensity of lawyers to include third parties such as directors, officers, employees, or contractors in contractual indemnities, one must be aware of the uncertainty of enforcement of such provisions, and whether an alternative approach should be taken to protecting the interest of those third parties.

\section{OIL FIELD SERVICE AND DRILLING CONTRACTS - IS CANADA OUT OF STEP WITH THE REST OF THE WORLD?}

With some exceptions, our Canadian common law system has historically allocated liability based on causation and fault. In contradistinction to other jurisdictions, we have not seen significant legislative or judicial interference with the operation of these principles. It is probably safe to argue that these are the predominant principles for risk allocation in most commercial agreements used, or drafted for use, in Canada.

This section of the article examines the relatively new but growing use of no-fault risk allocation provisions, commonly known as "knock-for-knock" clauses, in Canadian energy industry agreements. Knock-for-knock clauses are also sometimes called reciprocal or mutual indemnities, but we will use the term "knock-for-knock" for the purposes of this article to avoid confusion with use in Canada of the terms "reciprocal" and "mutual" to describe indemnities between parties that mirror each other but may be based on fault.

SNB 1993, c L-1.2, s 4.

Maria Lavelle, "Privity of Contract and Third Party Beneficiaries" (Paper delivered at the Uniform Law Conference of Canada - Civil Law Section, September 2007) at 9, online: Uniform Law Conference of Canada <http://wwwulcc.ca/en/poam2/index.cfm?sec=2007\&sub=2007g>. 
The origins of knock-for-knock indemnities may have come from maritime or admiralty law as a result of the perils of the sea doctrine. ${ }^{98}$ During World War II, the Allied governments entered into knock-for-knock agreements covering collisions between their ships. ${ }^{99}$ This principle also found its way into other industries such as the insurance industry, where it is common for insurance companies to enter into knock-for-knock agreements where regardless of cause, each insurer will indemnify for damages and injuries suffered by its own insured. The construction industry, particularly offshore construction, also makes use of knock-for-knock regimes. ${ }^{100}$ Today, it is generally accepted in numerous jurisdictions that a knock-for-knock indemnity regime provides an efficient method of allocating risk in construction and oil field services agreements.

For some time, Canada has seemed out of step with much of the rest of the world in relation to risk allocation in service agreements used in the oil and gas industry and the use of knock-for-knock indemnities. However, knock-for-knock provisions have recently begun to find their way into Canadian service provider agreements, including those published by the Petroleum Services Association of Canada and the Canadian Association of Oilwell Drilling Contractors. Similar provisions, in contrast, have been found for many years in the international standard agreements drafted by bodies such as the International Association of Drilling Contractors and the Association of International Petroleum Negotiators, as well as the standard oil field service contracts used by the larger oil field service companies such as Schlumberger, Baker Hughes, and Halliburton. These types of provisions have not yet found their way into the standard agreements developed by Canadian oil and gas companies to contract for oil field services. We are aware of one prominent Canadian oil and gas company that has recently changed the risk allocation provisions in some of its standard agreements from a knock-for-knock scheme to one that is fault-based, and another that does not use indemnity provisions, leaving the parties to rely on their common law rights and remedies.

The following is a generic example of a knock-for-knock indemnity prepared for the purposes of this article:

\subsection{For the purposes of this Article, the following definitions shall apply:}

“Affiliate” means any company or legal entity which (a) controls either directly or indirectly a Party hereto, or (b) which is controlled directly or indirectly by such Party, or (c) is directly or indirectly controlled by a company or entity which directly or indirectly controls such Party;

“Contractor Group” means Contractor, its subcontractors, its Affiliates and its and their respective directors, officers, employees, agents, and invitees, including the heirs, representatives, or successors of same; at 779 .

$99 \quad$ Ibid.

100 See e.g. Maria Manuela Andrade, "Knock for Knock Indemnities: Contract Practices and Enforceability Issues," Oil, Gas \& Energy Law [forthcoming with advance publication on 24 March 2011] at 3. 
“Owner Group” means Owner, its Affiliates and its and their respective directors, officers, employees, agents, and invitees, including the heirs, representatives, or successors of same, but shall not include any member of the Contractor Group;

Contractor shall be responsible for and shall save, indemnify, defend and hold harmless the Owner Group from and against all claims, losses, damages, costs (including legal costs on a solicitor-client basis), expenses, and liabilities in respect of:

(a) loss of or damage to property of the Contractor Group whether owned, hired, leased, or otherwise provided by the Contractor Group arising from or relating to the performance of the Services; and

(b) personal injury including death or disease to any person employed by the Contractor Group arising from or relating to the performance of the Services.

Owner shall be responsible for and shall save, indemnify, defend, and hold harmless the Contractor Group from and against any claims, losses, damages, costs (including legal costs on a solicitor-client basis), expenses, and liabilities in respect of:

(a) loss of or damage to property of the Owner Group arising from or related to the performance of the Services; and

(b) personal injury including death or disease to any person employed by the Owner Group arising from or relating to the performance of the Services.

This example is put forward not as a precedent for a well-drafted clause, but to demonstrate the basic principles of a knock-for-knock indemnity.

It should be pointed out that knock-for-knock regimes do not include the contracting parties' liabilities to third parties not involved in the performance of the contract. These liabilities are usually allocated on a fault basis.

A knock-for-knock risk allocation scheme can have a number of benefits including:

- $\quad$ reduced time in negotiating risk allocation provisions;

- reduction of aggregate insurance premiums as a result of the elimination of redundant or overlapping coverage;

- the cost of investigating, negotiating, and settling the claim, or the cost of resulting litigation when a loss occurs, should be greatly reduced by the elimination of the adversarial process of determining fault; and

- in a high risk industry where safety is of utmost importance, the parties will be more willing to share information to possibly help avoid future accidents when such sharing of information will not expose a party to liability. 
On the other hand, opponents of knock-for-knock schemes might argue that they reward a party for wrongdoing and do nothing to discourage reckless or unsafe behaviour.

There are no legislative restrictions or prohibitions on the enforceability of knock-forknock indemnity provisions in Canada comparable to the anti-indemnity statutes described above that are found in a number of US oil and gas producing states. As pointed out above, a knock-for-knock indemnity provision will not be enforceable in Texas unless the agreement in question requires the parties to put in place insurance coverage specified in the TOAIS. In addition, because of the relatively recent adoption of knock-for-knock indemnities in oil field service and drilling contracts in Canada, there are no Canadian cases considering the enforceability of knock-for-knock provisions while there are reported decisions in other jurisdictions such as the US ${ }^{101}$ and the UK. ${ }^{102}$ Knock-for-knock provisions take many forms and as a result it is risky to make blanket statements about them, but there is no reason to believe that a well-drafted clause, taking into account the principles discussed in Part II, above, of this article, will not be enforceable in our common law provinces. ${ }^{103}$

When using knock-for-knock indemnities, it is important to ensure that the parties put in place insurance policies that cover the risks allocated to them. The parties should ensure that appropriate provisions are included, requiring that each of them be named as an additional insured along with the provision of mutual waivers of subrogation. Failure to advise one's insurer of the existence of an agreement providing for such a risk allocation scheme could adversely affect a party's right to coverage under its insurance policies. A detailed discussion of insurance implications is beyond the scope of this article, but it is an important topic that is worthy of note and some discussion. Larger clients will have the benefit of a risk management department to provide guidance in this area. Smaller clients will need to utilize insurance advisors or brokers for this purpose, but in either case, lawyers advising on these types of matters need to understand the links between indemnity and insurance provisions.

\section{The Purchase and Sale Agreement - Simple Transaction, COMPLEX ASSET - A LiABILITY REgIME FOR All OCCASIONS}

The rationale behind purely fault-based risk allocation provisions in commercial contracts would appear to be fairly obvious: parties should be responsible for a breach of their own contractual obligations and should be able to hold their commercial counterparties liable in the event of a similar, reciprocal breach. When one moves into consideration of tort law and the potential for third party claims to affect either party to a particular contract, a party ought logically to be further protected from damage suffered as a result of wrongful or negligent acts committed by a counterparty in undertaking the activities associated with a commercial arrangement, whether such damages arise directly to such party or to unrelated parties.

See e.g. Darty, supra note 47.

See e.g. Caledonia North Sea Ltd v London Bridge Engineering Ltd, [2002] UKHL 4, [2002] 1 All ER Comm 321.

This article does not address the enforceability of these provisions in Quebec, but with the possible development of shale gas reserves in Quebec and the then possible use of standard industry agreements, it may be advisable to address this issue in the future. 
However, as discussed above, the nature of commercial activities conducted in the energy industry often involve potential damages for breach of contract and in tort of such extraordinary magnitude that commercial parties are forced to mitigate the potential exposure to such damages through various contractual means. For instance, a provider of offshore drilling services and equipment simply would not (or simply could not) be willing to provide its services if it ran the risk of being liable for the enormity of damages that could arise from the sorts of catastrophes that can occur on offshore platforms. In this context, provisions excluding liability for consequential, special, and indirect damages and caps, deductibles, and thresholds are all means by which energy industry participants mitigate such risks. Contractual regimes allocating risk by way of indemnity, whether alone or in combination with provisions requiring the holding of insurance by one or more of the parties, are common and widely accepted methods for addressing such concerns. As with most industries, the assignment of fault in relation to any particular event or incident may be difficult, and while most industry players generally have confidence in the legal regimes in which they operate (or to which they attorn), they are equally unwilling or unable to bear the uncertainty associated with a determination of fault in relation to any particular incident or event.

That being said, it is virtually impossible to find examples of standard energy industry contracts that allocate risk purely on a fault basis. At best, some contracts represent a hybrid between fault-based and no-fault-based liability regimes and others may contain multiple fault regimes: one for each type of potential liability being faced by the parties to the contract. None of them however will contain a purely fault-based regime without some limitation or exclusion of damages or potential damages or some measure of no-fault allocation of risk such as exclusions for consequential damages, gross negligence, or wilful misconduct.

One example of an industry standard agreement that may contain provisions approaching a fault-based regime is a standard form oil and gas asset purchase and sale agreement insofar as such agreements tend to deal with misrepresentation or breach of warranty. It is important to note that such agreements tend to contain multiple liability regimes: a fault-based regime dealing with misrepresentation (and often breach of covenant), a no-fault regime dealing with environmental matters, a second no-fault adjustment regime that allocates responsibility for the obligations and benefits associated with the assets being sold based upon an agreed upon effective date, and yet another hybrid regime that may deal with the liability and obligations of the vendor in the period between the execution and closing of the agreement. Perhaps the best illustrative example of such an agreement is the 2000 Canadian Association of Petroleum Landmen's Property Transfer Procedure. ${ }^{104}$

Clause 13.00 of the Transfer Procedure deals with "Liability and Indemnification.” The article contains numerous provisions allocating "responsibility" to each of the Transferor and Transferee and also limiting the liability of both parties to the agreement. ${ }^{105}$ Clause 13.01 of the Transfer Procedure deals specifically with "Responsibility of Transferor" by providing the parties with the following two mutually exclusive options as follows: 


\subsection{Responsibility Of Transferor}

Alternate 1

Subject to Clauses 5.04, 6.04, 13.03 and 13.04 and provided Closing has occurred, the Transferor will:

(a) be liable to the Transferee for its Losses and Liabilities; and, in addition

(b) indemnify and hold harmless the Transferee and each of its directors, officers, agents and employees from and against all Losses and Liabilities;

as a direct result of the Transferor's breach, on or prior to the Closing Date, of any of the representations and warranties of the Transferor under this Agreement, except any Losses and Liabilities insofar as they are caused by a breach of the Transferee's representations or warranties under Article 6.00 or by the gross negligence or wilful misconduct of the Transferee, or any of its directors, officers, agents, employees or assigns.

Alternate 2

Subject to Clauses 6.04, 13.03 and 13.04 and provided Closing has occurred, the Transferor will:

(a) be liable to the Transferee for its Losses and Liabilities; and, in addition

(b) indemnify and hold harmless Transferee and each of its directors, officers, agents and employees from and against all Losses and Liabilities;

as a direct result of any matter attributable to the Assets and occurring or accruing prior to the Effective Date, except any Losses and Liabilities insofar as they are caused by the gross negligence or wilful misconduct of the Transferee, or any of its directors, officers, agents, employees or assigns. ${ }^{106}$

Alternate 1, as reproduced above, provides that the Transferor is to be liable to, and is to indemnify the Transferee, for any losses and liabilities "as a direct result of the Transferor's breach ... of any of the representations and warranties of the Transferor under this Agreement.” ${ }^{107}$ As such, the provision very clearly holds the Transferor accountable for its breach of the agreement and further provides the Transferee with a full indemnity in respect thereof. In that sense, Alternate 1 of the Transfer Procedure constitutes a fault-based concept of liability in that liability will only accrue to the Transferor in the event that it breaches its representations and warranties as provided for in the agreement. If the Transferor is found to have provided a misrepresentation or to have breached a warranty, it will be required to indemnify the Transferee (subject to certain other limitations).

Alternate 2 of Clause 13.01 of the Transfer Procedure represents an interesting departure from the more fault-based provision contained in Alternate 1 of the same section. Note that Alternate 2 imposes responsibility to the Transferor "as a direct result of any matter 
attributable to the Assets and occurring or accruing prior to the Effective Date."108 No mention is made in that provision of any breach of contract, representation, warranty, obligation, or duty of the Transferor. Rather, liability is imposed on the Transferor based solely upon the date upon which the event giving rise to liability occurred. This contrast between Alternates 1 and 2 of Clause 13.01 of the Transfer Procedure serves to usefully illustrate the differences between fault and no-fault-based liability regimes within this context. $^{109}$

Interestingly, the obligations of the Transferee (or purchaser) under the Transfer Procedure are not based on fault, in contrast to those assigning liability to the Transferor under Alternate 1 of Clause 13.01:

\subsection{Responsibility of Transferee}

Subject to Clauses 5.04 and 6.04 and provided Closing has occurred, the Transferee will:

(a) be liable to the Transferor for its Losses and Liabilities; and, in addition

(b) indemnify and hold harmless the Transferor and each of its directors, officers, agents and employees from and against all Losses and Liabilities;

as a direct result of any matter attributable to the Assets and occurring or accruing on or subsequent to the Effective Date, except any Losses and Liabilities insofar as they are caused by a breach of the Transferor's representations or warranties under Article 6.00 or by the gross negligence or wilful misconduct of the Transferor, or any of its directors, officers, agents or employees. The responsibility prescribed by this Clause, however, does not provide an extension of any representation or warranty under Clauses 6.01 and 6.03 or an additional remedy for the Transferee's breach thereof. ${ }^{110}$

Therefore, liability flows to the Transferee based upon its ownership of the assets as of the effective date (save and except where any losses and liabilities are caused by breach by the Transferor, or its gross negligence or wilful misconduct). It is interesting to contrast the varying obligations of the Transferor (fault-based liability) and those of the Transferee (nofault and based on ownership of assets).

Moving deeper into the Transfer Procedure and indeed most industry purchase and sale indemnity and liability provisions, one will typically find a separate no-fault-based indemnification in respect of environmental matters. The Transfer Procedure contains the following as its Clause 13.04:

Ibid.

It should be noted, however, that the Transfer Procedure was the only form of oil and gas asset purchase and sale agreement reviewed in the preparation of this paper that contained a no-fault-based liability regime relating to a vendor's (or Transferor's) responsibilities. As noted in the annotations to the Transfer Procedure, Alternate 2 is "generally not appropriate, assuming that the general caveat emptor principle ... is maintained.” Ibid. Based on our review, the authors would agree that no-fault liability regimes are very rarely used (if at all) in this context and are not appropriate under most modern oil and gas purchase and sale agreements.

Ibid, cl 13.02. 


\subsection{Assets Acquired On “As Is” Basis}

Provided Closing has occurred, the Transferee will:

(a) be solely liable and responsible to the Transferor for its Losses and Liabilities; and, in addition

(b) indemnify and hold harmless the Transferor and each of its directors, officers, agents and employees from and against all Losses and Liabilities;

as a direct result of any matter attributable to any Environmental Liabilities and Abandonment and Reclamation Obligations pertaining to the acquired Assets, regardless of the date from which they may have accrued. $^{111}$

These types of provisions specifically allocate all environmental risk associated with the assets (whether occurring prior to or after the effective date) to the Transferee. There has been much analysis of the underlying rationale behind such provisions in oil and gas purchase and sale contracts, and a lengthy discussion thereof is beyond the scope of this paper. The annotations to the Transfer Procedure offer a number of reasons for the inclusion of such provisions including: (1) the difficulty in assessing where abandonment and reclamation obligations begin and end from a temporal perspective; (2) the elimination of administrative burdens on the Transferor; and (3) the difficulty for a Transferor to defend a claim without baseline environmental studies being conducted. ${ }^{112}$ It is beyond question that provisions allocating all environmental risks to the vendor (or Transferor) are the industry norm and for the purposes of this paper can be identified as a no-fault risk allocation mechanism that, when paired with the fault-based regime for misrepresentation and breach of warranty provided by the vendor, creates the most important allocations of risk contained within a modern industry purchase and sale agreement.

In addition to the allocation of environmental and asset risk under a no-fault system, as well as the fault-based indemnification provided by the vendor, most industry standard purchase and sale agreements contain other mechanisms for limiting liability (usually of the vendor). For instance, most asset purchase and sale agreements preclude the recovery of special or consequential damages. Other common mechanisms contained within most asset purchase and sale agreements for reducing liabilities include: (1) liability caps under which the vendor's liability under the purchase and sale agreement is restricted to a certain monetary amount (such as the purchase price or a percentage thereof); (2) de minimus thresholds pursuant to which items creating indemnity obligations are required to meet certain individual or aggregated thresholds before the creation of liability on the vendor for a misrepresentation or breach of warranty; and (3) deductibles whereby a vendor is only obligated to provide indemnity for amounts in excess of a certain threshold.

By providing for such exclusions, industry has attempted to balance the needs of vendors to dispose of assets with limited trailing liability with the needs of purchasers who require at least some relief against the potentially harsh consequences of a sale transaction conducted 
on a strict caveat emptor basis. In that sense, the modern purchase and sale agreement represents the long-negotiated bargain between vendors and purchasers of the simplest of transactions (albeit relating to a fairly complex asset). Interestingly, this most simplest of transactions has spawned an industry standard agreement that incorporates a myriad of faultbased and no-fault-based liability regimes that also contain substantial limitations and exclusions to liability.

\section{THE JOINT OPERATING AgREEMENT OR CO-OWNERSHIP AgREEMENT - Allocating Risk FOR MUtUAL BENEFIT}

Joint operating and co-ownership agreements are two other extremely common forms of agreements used in the oil and gas industry. Whereas a purchase and sale agreement involves a one-off transaction pursuant to which parties attempt to offload liabilities onto one another in the post-closing period, a joint operating agreement must attempt to balance a continuing relationship whereby both parties will benefit from the efficient ongoing development of the jointly owned asset. As a result, a typical joint operating agreement or co-ownership agreement must strive to create a system whereby parties may appropriately share in not only the proceeds of development and operation, but also the risks associated therewith. Failure to do so will result in stifled development of the asset (because no operator will take the risk to operate and develop) or a loss of benefit to non-operating parties (because the operator will require increased compensation in exchange for taking on disproportionate development or operational risk).

Under most, if not all joint operating or co-ownership agreements, one party is appointed as operator and is charged with the day-to-day operation of the jointly owned asset. The operator's authority is typically restricted by various means including capping the operator's ability to expend funds from the joint account without approval and the institution of an approval process or, in more complex agreements, requiring approval from a management or operating committee in order to proceed with certain activities, operations, or initiatives. Under all such agreements however, the operator is provided with some form of authority to conduct operations on the jointly owned assets and is charged with overseeing the orderly and efficient development of those assets. The inherent difficulty with such an arrangement is that most parties will not be prepared to undertake risks disproportionate to their interest in the jointly owned assets in order to fulfill duties as an operator. The solution to such difficulty has been the adoption in most joint ownership or co-ownership agreements of a liability regime pursuant to which the operator is indemnified by all of the co-owners of the asset in proportion to their respective ownership interest therein. An example of provisions affecting such a regime is contained in the 1990 Canadian Association of Petroleum Landmen (CAPL) Operating Procedure as follows:

401 LIMIT OF LEGAL RESPONSIBILITY — Notwithstanding Clauses 303 and 304, the Operator ... shall not be liable to the other Joint-Operators, or any of them, for any loss, expense, injury, death or damage, whether contractual or tortious, suffered or incurred by the Joint-Operators resulting from or in any way attributable to or arising out of any act or omission, whether negligent or otherwise, of the Operator ... except: 
(a) when and to the extent that such loss, expense, injury, death or damage relates to a risk against which the Operator is required to carry insurance for the joint account .... and is within the limits of such required insurance (insofar as such limits exceed the deductible applicable thereto), provided that if the Operator had maintained the required insurance covering such loss, expense, injury, death or damage, the Operator shall be released from the responsibility and indemnity otherwise imposed by this Clause to the extent that the insurer thereunder is financially unable to pay all or any portion of a valid claim with respect to such loss, expense, injury, death or damage or such insurer is determined by a court of competent jurisdiction not to be required to make payment with respect to such loss, expense, injury, death or damage under such policy of insurance; and

(b) when and to the extent that such loss, expense, injury, death or damage is a direct result of, or is directly attributable to, the gross negligence or wilful misconduct of the Operator ... provided that an act or omission of the Operator ... shall be deemed not to be gross negligence or wilful misconduct, insofar as such act or omission was done or was omitted to be done in accordance with the instructions of or with the concurrence of the Joint-Operators.

To the extent that the conditions in Subclauses (a) or (b) of this Clause apply (but subject to the exceptions provided therein), the Operator shall be solely liable for such loss, expense, injury, death or damage and, in addition, shall indemnify and save harmless each other Joint-Operator ... in respect of any such loss, expense, injury, death or damage, and any costs and expenses relating thereto.

402 INDEMNIFICATION OF OPERATOR - Except as otherwise provided in Clause 401, the JointOperators hereby indemnify and save harmless the Operator ... from and against any and all actions, causes of action, suits, claims, demands, costs, losses and expenses resulting from loss, injury, death or damage respecting any person, which may be brought against or incurred or suffered by the Operator ... or which the Operator ... may sustain, pay or incur by reason of, or which may be attributable to or arise out of, any act or omission of the Operator ... in conducting joint operations. All such liabilities shall be for the joint account and shall be borne by the Joint-Operators in the proportions of their respective working interests. ${ }^{113}$

The general principle adopted in the Operating Procedure is that, save for two exceptions, the operator is absolved of all liability "whether contractual or tortious" and "whether negligent or otherwise" relating to the fulfillment of its duties as operator. ${ }^{114}$ Clause 402 of the CAPL Operating Procedure provides full indemnification to the operator in respect of any and all claims advanced against the operator and provides that "[a]ll such liabilities shall be for the joint account and shall be borne by the Joint-Operators in the proportions of their respective working interests." ${ }^{115}$ Without consideration of the two exceptions discussed below, the regime created appears to be one of no-fault, in that the operator is fully indemnified for its acts and omissions in the fulfillment of its duties as operator.

Clauses 401(a) and (b), however, create two notable exceptions to the general proposition that the operator will be absolved from liability associated with the fulfillment of its duties. The first relates to a requirement imposed upon the operator to obtain insurance for the joint of Petroleum Landmen, 1990), cls 401-402. 
account pursuant to clause 311 of the Operating Procedure. ${ }^{116}$ Under that provision, the operator is required to hold and maintain insurance for the joint account either at certain defined levels or as is required pursuant to regulation. ${ }^{117}$ Clause 401(a) serves to hold the operator liable for liabilities covered by the insurance the operator is required to maintain pursuant to clause 311 by excepting it out from the clause 401 provision which absolves the operator from liability. ${ }^{118}$ Importantly, not only does clause 401(a) effect such exemption for insurance that the operator actually carries but "against which the Operator is required to carry," under the Operating Procedure, it would nonetheless lose its ability to rely upon the limits to its liability and would in fact be required to indemnify the joint operators for any losses that would have been covered. Indeed, an annotation to the Operating Procedure makes such intention clear when it indicates that " $\mathrm{t}$ ] he inclusion of Subclause [401](a) ensures that the operator is directly responsible for the failure to carry required insurance.”120

The second exclusion to the absolution of liability to the operator is created by clause 401(b) and is an extremely common exclusion to commercial liability provisions. Clause 401(b) provides that the operator will be liable for and will indemnify the other joint operators from any liabilities caused by its gross negligence or wilful misconduct. ${ }^{121}$ A more fulsome discussion of exclusions for gross negligence and wilful misconduct can be found in this article, but it is important to note that the Operating Procedure is very clear to expressly provide the operator will not be liable for its own negligence, but it is equally specific with respect to the attachment of liability to the operator for its own gross negligence or wilful misconduct. Of further note is an "exclusion to the exclusion" contained in clause 401 which exempts the operator from liability associated with "loss or delay of production from the joint lands, including ... loss of profits or other consequential or indirect losses applicable to such loss or delay of production."122

In general terms, the liability regime created in the Operating Procedure represents one of the most common regimes in Canadian energy industry contracts. Most drilling and service contracts, joint and co-ownership agreements, processing agreements, purchase and sale agreements, and many other forms of agreements used in the industry make use of modified versions of this particular regime. The regime is clearly not entirely fault-based (in that the operator or service provider is usually provided with some form of indemnity), but neither can it be categorized as the type of knock-for-knock based regime discussed above since the parties are still exposed to some level of fault-based liability. In this context, parties should pay particular attention to the demarcation of a bright line between what sources of liability are treated as fault-based, and which are to be dealt with on a no-fault basis, and draft accordingly. 


\section{DRAFTING SUgGESTIONS}

When reviewing or drafting indemnity provisions, one should consider the following drafting issues:

- Do not treat an indemnity provision as if it were boilerplate when reviewing agreements drafted by other parties or when using your own firm or company precedents. Consider whether it is time to conduct a review of your standard indemnity provisions.

- Consider the risk that a court will invoke the doctrine of contra proferentem against indemnity provisions that you have drafted.

- Think carefully about what risk allocation scheme or schemes should be used in a particular agreement, including the scope of the indemnity and the parties that should be indemnified.

- If the parties intend for a contractual indemnity to provide the sole remedies of the parties under the agreement, ensure that this intention is clearly expressed and that no other provision of the agreement contradicts this intention.

- Ensure that there are no statutory limitations or prohibitions to the type of indemnity being used or proposed.

- Consider whether there may be public policy arguments against the enforcement of the indemnity in question. For example, indemnifying a party for its own wilful misconduct may not be enforceable.

- Draft clearly and unambiguously as suggested by the courts in numerous decisions. Vague or general wording such as "howsoever caused" should be replaced or supplemented with wording specifically setting out the intent of the parties. If a party is to be indemnified for its own negligence or gross negligence, its direct losses rather than only third party claims, or for its own breach of contract, specific wording should be inserted.

- If the indemnity is intended to benefit parties that are not party to the agreement, consider whether they should be made parties to the indemnity, either by agency, by signing the agreement in question, or by signing a separate indemnity agreement.

- In the case where a company is being asked to backstop the obligations of a subsidiary or affiliate, consider whether the provision should be written as an indemnity or a guarantee. In a general sense, an indemnity should have fewer obstacles to enforcement than a guarantee.

- In cases where gross negligence is either being included or excluded, consider whether the term "gross negligence" should be defined. 
- Do not use vague terms such as "indirect losses” or "consequential losses” on their own, but ensure that they are specifically supplemented with the types of losses that you are concerned about in a particular case, such as loss of profit or loss or revenue. Alternatively, consider defining “indirect losses” or “consequential losses.”

- If it is intended that a party will recover legal fees actually spent by it, ensure that the description of the legal fees will cover these costs. "Legal fees" or "attorney fees” on their own will not achieve this result. Wording such as "legal fees on a solicitor and his own client" basis or "legal fees on a full indemnity basis" has been considered to be acceptable by the courts for this purpose.

- An indemnitor should consider avoiding the term "save harmless" (or "hold harmless”) given the additional and arguably uncertain obligations that it imposes.

- If an agreement contains a complex indemnity provision, consider whether a "NonExclusive Remedies” clause will negate the effect of the clause.

- Be extremely careful when amending indemnity provisions, particularly with respect to the impact on other parts of the agreement in question.

- Consider whether there is a choice of law alternative that will allow one to better enforce its indemnity rights. In this regard, if it is available, consider maritime law.

- The insurance provisions must be carefully reviewed to ensure that they are appropriate and properly protect the parties. Expert advice is often desirable when conducting this review. Indemnity provisions at the very least should be supported by insurance obtained by the parties that name each other as a named insured and that provides a waiver of subrogation from the insurer. It goes without saying that an indemnity on its own, without adequate insurance backstopping it, may not be worth the paper it is written on. 